\title{
The Peaceful Teaching Method of Datok Sulaiman in Spreading Islam in Tana Luwu, Indonesia.
}

Bulu,

State Islamic Institute Palopo

bulu@iainpalopo.ac.id

Nuryani,

State Islamic Institute Palopo

nuryani@iainpalopo.ac.id

\author{
Abdul Rahim Karim, \\ State Islamic Institute Palopo \\ abdulrahimkarim@iainpalopo.ac.id
}

\begin{abstract}
This study discusses the teaching method of Datok Sulaiman in spreading Islam in Tana Luwu, South Sulawesi, Indonesia. This study employed historical and sociological approaches to unpack those research aims. The research findings show that the teachings of Islam transmitted throughout Tana Luwu region used a peaceful approach without involving any violence with the support of Datok Luwu. Datok Sulaiman mostly used dialogue, Sufistic, and supernatural approaches to spread Islam. Therefore, he could successfully spread Islam in Tana Luwu, including the conversion of XV King Luwu in 1603 which influenced the rapid conversion of Islam in the area.
\end{abstract}

Keywords: peaceful Islam; teaching methods; Datok Sulaiman; Tana Luwu; peace; dialog; Sufism; supernatural;

\begin{abstract}
Absttrak
Studi ini membahas metode pembelajaran Datok Sulaiman dalam menyebarkan Islam di Tana Luwu. Sulawesi Selatan, Indonesia. Pendekatan yang digunakan adalah pendekatan historis dan sosiologis. Analisis yang digunakan adalah reduksi data, penyajian data, dan penarikan kesimpulan. Hassil penelitian menunjukkan bahwa ajaran Islam berkembang pesat di seluruh wilayah Tana Luwu secara damai tanpa kekerasan berkat peran Datok Sulaiman. Metode pengajaran Islam damai yang digunakan oleh Datok Sulaiman adalah dialog, pembelajaran sufisme, dan supranatural. Hal ini berdampak pada adanya dukungan Raja Luwu XV pada 1603 M, sehing a agama Islam berkembang dengan cepat.

Kata kunci: Islam damai; metode pengajaran; Datok Sulaiman; Tana Luwu; perdamaian; dialog; tasawuf; supranatural
\end{abstract}




\section{Introduction}

The acceptance of Islam in several places in the archipelago shows two different patterns.1 First, Islam was first accepted by the lower classes, then developed and accepted by the upper classes or the ruling elite. The first pattern is usually called the "bottom up". Second, Islam is accepted directly by the ruling elite. Then, socialized and developed to the people below. This last pattern is usually called the "top down".

The acceptance of Islam in several places in Indonesia shows two patterns. First, Islam was accepted by the lower classes, then accepted by the upper classes or the elite. This first pattern is usually called the "bottom-up". Second, Islam directly accepted by the elite and spread to the people below. This pattern is usually called the "top-down".2

Theories about the process of spreading Islam in Tana Luwu stated that Datok Sulaiman was the first person that brings Islam to Tana Luwu. He is known as Khatib Sulung Sulaiman, originally from Minangkabau, West Sumatera. He is also known to be a very instrumental person in the spread of peaceful Islam 3 around the XV century $\mathrm{M}$ without causing unrest among the Luwu kingdom and society.

This article aims to find out what learning and teaching methods are used by Dartuk in the spread of peaceful Islam in Luwu.

\section{Research Method}

This type of research is descriptive qualitative. Data collection techniques carried out by combined triangulation of interviews, observation, and documentation. Data analysis is inductive. The results of qualitative research emphasize the meaning rather than generalization. 4

1 Ahmad M. Sewang, Islamisasi Kerajaan Gowa: Abad XVI Sampai Abad XVII (Yogyakarta: Yayasan Obor Indonesia, 2005), 87.

2 Ahmad M. Sewang, Islamisasi....2005.

3 Sarita Pawiloy, Ringkasan Sejarah Luwu (Makassar: Telaga Zamzam, 2002), 63.

4 Sugiyono, Metode Penelitian Kuantitatif Kualitatif Dan R\&D (Bandung: Alfabeta, 2009), 8. 
Additionally, Mardalis revealed that qualitative research seeks to describe, record, analyze and interpret the things studied through observation, interviews, and study documentation 5. Qualitative research provides a systematic, accurate, and accurate picture of the spread of Islam in its early development in Tana Luwu.

This research was conducted in Tana Luwu. Tana Luwu covers Palopo City, Luwu Regency, North Luwu Regency and East Luwu Regency. Data is collected in three Subdistricts / cities, namely; Luwu Regency, namely in Bua Subdistrict. North Luwu Regency Malangke Subdistrict, and in Palopo City. These three regencies / cities became the spreading regions of Islam in Tana Luwu. Bua Subdistrict was chosen because it was in this area that Datok Sulaiman's boat first docked and set foot in Tana Luwu, meeting Maddika Bua Tandipau, precisely at La Pandoso. Malangke Subdistrict in North Luwu Regency was chosen as the location of the study because this area became the center of the government of the Luwu kingdom and Datu Luwu Andi Patiware who first converted to Islam. And the City of Palopo because Palopo became the place of the kingdom of Luwu after being moved from the kingdom of Luwu from Pattimang to Palopo. And built the Old Jami' Mosque in 1604 M, a year after Datu Luwu converted to Islam.

The approaches used in this study are (1) historical approach, namely by obtaining valid past data regarding the spread of Islam in Tana Luwu, and (2) sociological approach, which is the approach used by Datok Sulaiman in spreading Islam, including its influence on religious emotions Tana Luwu community.

Data sources include; (1) Primary data sources, namely authentic data or data originating from the first source. 6 Obtained through interviews of religious leaders and community leaders. (2) Secondary data derived from searching various

5 Mardalis, Metode Penelitian; Suatu Pendekatan Proposal (Jakarta: Bumi Aksara, 2004), 4.

6 Hadari Nawawi and Mimi Martini, Penelitian Terapan (Yogyakarta: Gajah Mada University Press, 1996), 216. 
references, both sourced from books or other reference sources related to the theme of this study.

Data collection methods are (1) An interview is a conversation that is guided by someone with a specific purpose, usually between two parties or sometimes more to get information from others. 7 This was also similarly stated by Husaini and Purnomo who stated that the interview was an oral question and answer between two or more people directly.8 (2) Documenting as a source of data through historical artifacts that witness history in the spread of Islam in Tana Luwu which includes the La Pandoso monument as the anchorage of the boat used by Datok Sulaiman, Datok Sulaiman Tomb, and the Old Jami' Mosque in Palopo City. Through a literature search of various references, both sourced from books or other reference sources relating to the theme of the research discussion. Documentation, namely the study of documents through written goods. 9

The process of data analysis refers to Miles and Huberman's data analysis techniques.10 Done through three stages, namely; data reduction, data presentation and conclusion drawing.

\section{The Role of Datok Sulaiman in Spread of Islamic Religion}

Syarifuddin Daud as a religious figure and Chairperson of the Indonesian Ulema Council (MUI) of Palopo City revealed that in the spread of Islam in Tana Luwu, there are three regions I Subdistricts; Bua Subdistrict, Malangke Subdistrict, and Palopo City are the first areas of the spread of Islam in Tana Luwu, South Sulawesi.11

The three Subdistricts until now there is still evidence of Datok Sulaiman's legacy as the first propagator of Islam in Tana

7 Mohammad Tholchah Hasan, Metode Penelitian Kualitatif (Malang: Lembaga Penelitian Universitas Negeri Malang, 2002), 151.

8 Husaini Usman and Purnomo Setiady Akbar, Metode Penelitian Sosial (Jakarta: Bumi Aksara, 2001), 59.

9 Suharsimi Arikunto, Prosedur Penelitian Suatu Pendekatan Praktik (Jakarta: Rineka Cipta, 1992), 200.

10 Sugiyono, Metode Penelitian Kuantitatif Kualitatif Dan R\&D (Bandung: Alfabeta, 2009), 243.

11 Syarifuddin David, "Interview, August 29, 2019" 
Luwu: The First Bua Subdistrict; The religion of Islam initially entered the Bua area (precisely in La Pandoso' Pabbarasseng Village, Bua Subdistrict, Luwu Regency today), which was carried by three Islamic missions originating from Minang Kabau namely Sulaiman (Eldest Khatib) as the leader, Abdul Makmur (Single Khatib) and Abdul Jawad (Youngest Khatib). Before heading to Luwu, the three first stopped at Makassar, then continued their journey to Luwu. In Luwu the three arrived at La Pandoso, at the mouth of the Pabbarasseng River in the Bua area by sailboat named Qimara.12

A similar opinion was expressed by Siodja Daeng Mallondjo13 that before the arrival of the Islamic propagators, one night Maddika Bua had a dream of seeing three sunrises rising east of Bua. The light is so bright, that the angles that are normally unreachable by eye sight are clearly visible. However, when his gaze swirled around him, at that moment he also awoke from his dream. This dream is believed by Maddika Bua as a sign both for herself and her people.

Upon arrival in Bua, they met with a local fisherman named Latiwajo. On Latiwajo's information, Maddika Bua sent his envoy named Langkai Bukubuku to meet Abdul Makmur, Khatib Sulaiman and Khatib Bungsu by using a battleship named La Uli Bue, or a peanut shell boat.

Idwar Anwar 14 revealed that present at the meeting with Abdul Makmur, Khatib Sulaiman and Khatib Bungsu, namely some traditional Bua instruments consisting of: Maddika Bua as Chair Person of Customary Affairs, Pabbicara, Anri Guru To Magawe or Sakti, Pabunture or Pati, Opu to Malompom, Ampu Lembang to Maroa, and Tomakaka Posi. At the meeting Maddika Bua together with some of his entourage held a Singkarume (Dialogue) with Abdul Makmur, Khatib Sulaiman and Khatib Bungsu. They dialogue, about various things

12 Idwar Anwar, Sejarah Luwu: Mengurai Catatan Ringkas Sejarah Luwu Sebelum Kemerdekaan (Palopo: Pustaka Sawerigading, 2010), 128.

13 Siodja Daeng Mallondjo, Kedatuan Luwu: Catatan Tentang Sawerigading, Sistem Pemerintahan Dan Masuknya Islam (Palopo: Komunitas Sawerigading, 2008), 69.

14 Idwar Anwar, Sejarah Dan Kebudayaan Luwu (Palopo: Pustaka Sawerigading Arung, 2016), 131. 
especially about the teachings of Islam. In addition, Maddika Bua and Datok Sulaiman also held a magic contest. In this magical battle, Maddika Bua and Datok Sulaiman each showed their ability to understand the meaning and nature of life. Finally, after being truly convinced of the truth of the religion of Islam, Maddika Bua (Tandipau) and its adat stakeholders were sincerely embracing Islam.

Nurman Said as a religious figure, revealed that by embracing Islam, Maddika Bua and some of his traditional stakeholders, Datok Sulaiman's initial steps had the opportunity to easily develop Islamic religion in Tana Luwu. 15

Furthermore Idwar Anwar16 revealed that after the religion of Islam was well received by Maddika Bua and its adat stakeholders, Islam slowly developed in Bua. This area then became the initial basis of the development of Islam in Tana Luwu. When many Bua people converted to Islam, including some of the surrounding areas during this period, a simple house of worship was established on 1 Rajab $1013 \mathrm{H}$ in the Tanarigella Hamlet. The architecture of the mosque building is very simple.

In order for religious activities at the mosque to run well, after the construction of the mosque was completed, Datok Sulaiman formed a mosque administrator known as Parewa Syara'. The institution is expected to help the process of spreading Islam in Tana Luwu, especially in Bua.

Nurhidayat Said as a religious figure revealed that the composition of the Parewa Syara' consists of: 1) Kadi (Religious Judge). People who served this task, are required to have extensive knowledge about the Shariah Law. 2) Imam of the Mosque (Prayer Leader). 3) Khatib (Sermon Reader) must have knowledge of the Shariah law. 4) Bilala' (Voice of Adhan). 5) Addoja / Doja (Sustainer Masjid), they are tasked with guarding and managing mosques and those related to Islam and not classified as slaves.17 The establishment of the Parewa

15 Nurman Said, "Interview, July 19, 2019".

16 Anwar, Sejarah Luwu: Mengurai Catatan Ringkas Sejarah Luwu Sebelum Kemerdekaan (Palopo: Pustaka Sawerigading, 2010), 136.

17 Nurhidayat Said, "Interview, July 19, 2019". 
Syara' (Shara' Employees) became the forerunner of the syara' set in the entire Tana Luwu region.

Nasrul Sioja, one of the community leaders, explained that the shara' employees who were appointed were those who were already proficient in the field of religion, primarily reading the Qur'an, the descendant of the king at the suggestion of members of the Bua custom.18

On the other hand Annas Sioja explained that Datok Sulaiman as an Islamic mission had tried to teach Islam without being tired. When they felt confident that the people of Bua had been able to practice the teachings of Islam, Datok Sulaiman wanted to see Pajung or Datu Luwu again. The proposal was accepted by the local community and Maddika Bua (Tandipau) itself with the provision that Datok Sulaiman could keep a book or a guide or a handbook that could be used as a guide in the implementation of Islamic teachings.19 Maddika Bua's wish was granted by Datok Sulaiman by presenting a book to explore the teachings of Islam.

A similar opinion was expressed by Siti Ana as a community leader that convincing evidence about Islam entered the first time in Bua is by the handwriting Datok Sulaiman himself left in Bua about the teachings of monotheism, fikhi, morals and others related to Islamic teachings. The book is written in Malay Arabic letters.20 The book is still preserved and well preserved by old people in Bua.

Muhammad Arafah, a religious figure, revealed that after submitting the book to Maddika Bua (Tandipau), the three missions departed along with Maddika Bua, Kadi Langkai and his guards to the center of the Luwu royal government located in Malangke to meet Datu Luwu. They used the Qimara boat (third missionary boat) and Lauli Bue' (Maddika Bua Battleship).21 In the sea journey by boat from Bua to Malangke, it was not too long ago.

18 Nasrul Sioja, "Interview, August 2, 2019".

19 Annas Sioja, "Interview, August 30, 2019".

20 Sitti Ana, "Interview, August 2, 2019".

21 Muhammad Arafah, "Interview, August 30, 2019”. 
Second, Malangke Subdistrict; Muhammad Idris, a religious figure, revealed that before entering the kingdom of Luwu, Datok Sulaiman and his friends first studied the situation and condition of the powerful King Luwu, that is, they got information from Maddika Bua to supplement the information that had been previously learned while still in Johor. 22 The initial information received in Johor was information through Luwu people who wandered there long before Datok Sulaiman came to Tana Luwu.

Idwar Anwar23 revealed that because Andi Patiware had put a sympathetic attitude towards Datok Sulaiman's very pious and friendly behavior, there were always discussions between Datok Sulaiman and Andi Patiware at any time. Finally, Datu Luwu (Andi Patiware) converted to Islam on Friday the $15^{\text {th }}$ of Ramadan 1013 H / 5 February 1603 M. He was later given the title of Sultan Muhammad Mudharuddin, and when he died was given the title Matinroe ri Ware'.

Sioja Daeng Mallondjo24 expressed his opinion that after the entry of Islam in the Luwu Subdistrict had given another color to people's lives. This can be seen by the increasing norms that become the guidance of society. These norms have implications for the daily activities of the community, especially in the implementation of various religious activities. For example, with the Friday prayers and various other religious rituals that he had previously performed. Islam also expanded rapidly to all parts of the kingdom of Luwu. Society can accept well the various teachings contained in the religion of Islam.

When His Majesty the Pajung / Datu (Andi Patiware) accepted Islam as his religion of belief, a happy event was immediately announced to the entire territory of the Kingdom of Luwu in the hope that all the people would follow in the footsteps and steps of Datu Luwu who had embraced a religion that brought true happiness. Based on the Ade' Seppulu Dua, the

22 Muhammad Idris, "Interview, August 3, 2019".

23 Anwar, Sejarah Luwu: Mengurai Catatan Ringkas Sejarah Luwu Sebelum Kemerdekaan (Palopo: Pustaka Sawerigading, 2010), 132.

24 Mallondjo, Kedatuan Luwu: Catatan Tentang Sawerigading, Sistem Pemerintahan Dan Masuknya Islam (Kota Palopo: Komunitas Sawerigading, 2008), 106. 
religion of Islam was later made the official religion of the Luwu Embassy.

Nidal Waje as a community leader revealed in an interview that Ade' Seppulu Dua are; 1. Pajung / Datu, Cenning (as a substitute for Pajung / Datu if unable to attend, 2. Penghulu Sara', 3. Pakkatenni Ade', 4. Makole Baebunta, 5. Maddika Bua, 6. Maddika Ponrang, 7. Anre' Guru Anakarung, 8. Anre' Guru Attoriolong, 9. Anre' Guru Pampawa Epu, 10. Matoa Wage, 11. Matoa Cenrana, and 12. Matoa Laleng Tonro.25 Ade' Seppulu Dua, served as a government implementing agency that helps Pajung/ Datu in running the government. After Islam as the official religion of the unity, the implementation of the teachings of Islam in the unity of Luwu began to be applied gradually. Old values that do not conflict with Islamic teachings are still in effect. While habits that are contrary to the teachings of Islam began to be abandoned.

Jabani as a religious figure revealed that the religion of Islam was easily accepted by the Luwu society, among the reasons being: 1) The concept of teachings (divinity) brought by Islam is believed to be almost the same as the concept of values (divinity) in the ancient teachings of Luwu society. 2) The Luwu society consider that the religion of Islam brought by the Prophet Muhammad is the same as that taught by Sawerigading. Luwu people understand that Sawerigading and Muhammad: ... iya muto, ... iya muto (he too, ... that too). 3) The religion of Islam has been accepted by Datu Luwu (Andi Patiware) and has become the official religion of the Luwu Embassy. 4) The compliance and trust of the Luwu community towards Datu Luwu (Andi Patiware) is very large.26 Datu Luwu in running the wheels of government applies a legal system in accordance with Islamic teachings.

Idwar Anwar 27 revealed that Datu Luwu applied Islamic teachings in running the government with reference to Datok Sulaiman's advice as follows: 1) A Pajung / Datu must always

25 Nidal Waje, “Interview, August 31, 2019”.

26 Jabani, "Interview, August 1, 2019".

27 Anwar, Sejarah Dan Kebudayaan Luwu (Pustaka Sawerigading Arung, 2016), 62. 
act fairly, honestly and behave properly, 2) One day Pajung / Datu do justice, it is equal to prayer 40 days and 40 nights, 3) Pajung / Datu only be set trade, but were not allowed to trade, and 4) Embassy should keep an eye on market participants to behave honestly in the trade.

The important role performed by Datok Sulaiman backed by Luwu embassy in spreading the teachings of Islam, 28 Luwu embassy especially in areas such as: 1) Applying the teachings of Islam in government and legal system in Luwu embassy. 2) Incorporating elements of Islam (Pagulu syara'/Datunna syara'/kadi) in Luwu embassy as structure one of the elements Ade' Seppulo Dua (Hadat 12). 3) Making the palace as a center of Islamic religion. 4) Educate prospective scholars who will serve as announcer Islam. 5) Sent envoys to various parts of the region Luwu embassy to broadcast the Islamic religion. 6) Forming prayer groups, to build houses of worship.

Third, Palopo City; The rapid development of Islam in the kingdom of Luwu reached its peak during the reign of Datu Luwu or Pajung Luwu XVI Pati Pasaung Toampanangi, Sultan Abdullah Matinroe Ri Malangke who succeeded his father in early 1604.

Abdul Muin Razmal as a community leader explained that at the beginning of Sultan Abdullah's government he moved the capital of the Luwu kingdom from Patimang to Ware Palopo. Consideration of this transfer is based on the strategic technical governance and the development of Islamic teachings. To support the development of Islam, Datok Sulaiman succeeded in establishing a permanent mosque in $1604 \mathrm{M}$ in the middle of Palopo City not far from the palace. 29 The mosque that was built was named the Old Palopo Mosque.

Harisal A. Latif 30 revealed that the transfer of the center of the Luwu kingdom to Palopo was followed by the construction of a magnificent mosque. The building is very sturdy and has a

28 Anwar, Sejarah Dan Kebudayaan Luwu (Pustaka Sawerigading Arung, 2016), 135.

29 Abdul Muin Razmal, "Interview, August 1, 2019”.

30 Harisal A. Latief, Kedatuan Luwu: Dalam Lintasan Sejarah Dan Kebudayaan (Palopo: Pustaka Sawerigading, 2018), 311. 
unique shape that is named the mosque Jami' (Old) Palopo. It has a grand pole made of strong and hard wood. It is said that there are forty people who employ carpenters. Each sculptor is assisted by forty sharpeners. No less than a thousand people are involved every day in the completion of the Jami' (old) Palopo mosque. The construction of the Jami' (old) Palopo mosque, marked by the erection of a single pillar pillar that serves as a support for the top of the overlapping roof top. The placement of the pillar which was installed earlier, right in the middle of the mosque building is an adjustment to the tradition of building the Luwu community.

Idwar Anwar31 stated that in addition to the view of Sufism, the element of monotheism also became the basis in the construction of the Jami (old) Palopo mosque. The element of monotheism is related to the three-level roof symbolization of the Jami' (old) Palopo mosque which consists of; Islam, faith and ihsan. The relationship between the three elements of monotheism with the symbolic structure of the roof of the Jami' mosque are: 1) Islam (which means the surrender) are denoted with the roof down along with body building. In the context of cultural symbolism Luwu this section can be interpreted lempu (honest). 2) Faith (which means trust or justification) symbolized by the roof level two (middle). In the context of cultural symbolism Luwu this section can be interpreted tongeng (right). 3) Ihsan (which means goodness virtuous or a deed earnest to devote themselves to Allah) is represented by a threelevel roof. In the context of cultural symbolism Luwu this section can be interpreted getteng (assertive and courage). 4) At the peak level of the mosque (mustaka) symbolizes the "position" of God, know God Most High. In the context of cultural symbolism Luwu this section can be interpreted adele' (justice).

Raja group and clan members readily accept Islam as their religion, even Islam is not a new one but only as a refinement of everything. That is why the Islamic easily expand to all corners of Tana Luwu and surrounding area. This can be seen in their

31 Anwar, Sejarah Dan Kebudayaan Luwu (Pustaka Sawerigading Arung, 2016), 142-143. 
confidence before the advent of Islam, which is to worship God "Dewata Sewwa-E" which he considers it creates and manages the entire contents of the universe.

Datok Sulaiman explained that God was referring to " Dewata Sewwa-E " is God Almighty, Who created the universe with all its contents. Datok Sulaiman heard the explanation that it is Datu Luwu together all clan members decided to embrace Islam as a whole as well as the full awareness of performing all the religious obligations as a consequence of their recognition. This can be seen in pangngadareng system ie the teachings of Islam incorporated therein.

Related to that Mattulada 32 argues as follows; Eppami uangena pedecengie tana, iami nagenne'lamampuangeng, manapi nani asellengeng naripattama tona sara'e seunai adee, maduanna rapance, matelunna ware'e, maeppa'na bicarae, malimanna sara'e... it means: Four kinds of aspects that improve the state, then five kinds are fulfilled, when it comes to Islam and also included shara' Islamic first is Ade', second is rapang, third is wari, and fourth is talk.

The acceptance of Islam and the making of Islamic sharia as an integral part of the pangngadareng, the socio-cultural institutions of the Bugis in general, especially Luwu people get a new color because the sharia provides a role in a variety of social and cultural life behaviors, their concept of Islamic values does not change much the social and cultural values which already exists.

\section{ASPECTS OF RELIGION TEACHING}

M. Said Mahmud as religious figures reveal that aspec teachings of Islam that developed in Tana Luwu is the aspect of faith and sharia.33

The First, Aspects of Aqeedah; Lahajji Patang expressed the opinion that the aspect of faith that developed because people have had confidence Tana Luwu "Dewata Sewwa-E", meaning God for everything. This can be seen in the sense of the

32 Mattulada, Islam Di Sulawesi Selatan (Jakarta: CV. Rajawali, 1983), 21.

33 M. Said Mahmud, “Interview, June 18, 2019”. 
divinity of the king of Luwu earlier before the advent of Islam, and became hereditary inherited beliefs as in lontara Luwu language. 34 The most substantive nature of the Islamic faith is monotheism, ie the Oneness of Allah. All elements of Islamic theology should be geared from this concept. The underlying belief in Allah Islamic person. As a consequence, monotheism will be of key importance in religious activity. Creed or monotheism, as the most fundamental and essential teachings of Islam, a determinant of good and bad Islam a Muslim. As the principal teachings of Islam, faith and monotheism is the beginning and the end of the call of Islam.Aspects of faith is developed by a preacher whose great merit in Luwu kingdom, namely Datok Sulaiman thus managed to convert Andi Patiware (King Luwu XV) together with their clan members, then followed his people as loyal followers.

Second, Aspects of Shari'a ;Syarifuddin Daud as a religious figure and Chairman of the Palopo City of MUI revealed that the syariah aspect was taught by Datok Sulaiman because at the beginning of the development of Islam in Tana Luwu there were still customs that were worked on for those deemed not to endanger the orderly public, such as when someone died before the body was removed. fertility then the family who died cut a chicken until it broke its head with the understanding that the accident of death does not quickly come in the near future. 35

A similar opinion was expressed by M. Sanusi Dg. Mattata36 that religion is very important to be known by the community as signposts in the teachings of Islam, establish Islamic law in Tana Luwu can be seen in traditional institutions 12 , where the qadi is placed as one of the members as well as an advisor Datu Luwu. Kadi designation as one member of the customary 12 is intended to control and maintain that any decision of these bodies should be adjusted with the Islamic sharia. Thus, people who become kadi must really know the

34 Patang, Luwu Dalam Pembangunan (Palopo: Usaha Makmur, 1982), 18.

${ }_{35}$ Syarifuddin David, "Interview, July 18, 2019".

36 M. Sanusi Dg. Mattata, Luwu Dalam Revolusi (Ujung Pandang: Bakti Baru, 1967), 91. 
teachings of Islam and permeates the law in it. In addition, it is intended also to ensure that action can be controlled Datu Luwu of irregularities Islamic law. Kadi is the holder of discretion in implementing Islamic law. For it was made a basic law that guarantees on it that reads "Pattupui riada, pasanrae risare, muattangnga' rirappangnge, mupattaratei riwarie, mualai pepegau ripobiasangnge" (apply to adat, lean to syara ', pay attention to the condition of the community and compare it to habits). Sharia is from Allah, the source of sharia comes from Allah, who is delivered by Allah to humans through the intercession of His Messenger.

\section{METHOD OF ISLAMIC TEACHING DATOK SULAIMAN}

Jabani as a religious figure revealed that the method used by Datok Sulaiman in spreading Islam in Tana Luwu was; dialogue, Sufism method, and magic fighting. 37 These three methods are: The First, Dialogue method; The method is a path that must be taken by someone to achieve a goal the better the method used the more effective the achievement of goals. And the event of the conversion of Datu Luwu seems to be marked by an open dialogue between His Majesty Datu Luwu and Datok Sulaiman. This incident was witnessed by many people, especially the royal officials.

M. Sanusi Dg Mattata 38 revealed that the method of dialogue lasted several days in a calm atmosphere, discussed and examined all aspects of Islam, especially in matters of worship, government, economics, and the issue of faith. The open dialogue ended with the sincere treatment of Datu Luwu Andi Patiware Daeng Parabung and the staff of the kingdom, of the beauty of Islam with the existence of the book (Al-Qur'an) as a guide and guide to life with no doubt in it.

Taufik Abdullah39 stated that Datok Sulaiman spread Islam by prioritizing the teachings of monotheism (aqeedah) using the

37 Jabani, “Interview, July 17, 2019".

38 Mattata, Luwu Dalam Revolusi (Ujung Pandang: Bakti Baru, 1967), 71.

39 Taufik Abdullah, Agama Dan Perubahan Sosial (Jakarta: CV. Rajawali, 1983), 231. 
old belief approach, the Sawerigading belief, Dewata Sewwa-E. In line with this opinion, Ritha Ikhsan as a community leader revealed that at the beginning Islam was spread in Tana Luwu easily accepted by Datu Luwu because the teachings brought by Datok Sulaiman were monotheistic teachings, in line with the teachings of the Dewata Sewwa-E which had been the trust of the Luwu society for a long time.40

On the issue of monotheism, Datok Sulaiman outlines in the form of dialogue with Datu Luwu and a number of royal relatives, with a variety of reasons, imagery or similars that are easily accepted. The teaching method used by Datok Sulaiman was to open the mind wide. Datu Luwu and the royal staff, examined the issue of the oneness of Allah. by inviting them to watch while researching everything that moves.

Datok Sulaiman's teaching method opens up Datu Luwu's insight to wander above the vast, unlimited universe, observing all the events that occur between heaven and earth and their contents. All of the evidence is undeniably real proof of the existence of Almighty God. See and examine the natural beauty of such a neat creation and composition, and pay close attention to all things that move, and arrived to conclusions that ensure that the beautiful and vast nature must have created it, and all those who move must have moved, namely God cried all nature.Thus, finally Andi Patiware together with his followers accepted Islam as his religion on the $15^{\text {th }}$ of Ramadan $1013 \mathrm{H}$ or $1603 \mathrm{M}$ and they accepted Islam softly and peacefully.

Second, Sufism Method; Syarifuddin Daud as a religious figure and Chairman of Palopo City of MUI explained that Datok Sulaiman in spreading Islam using the Sufism approach, he lived in simplicity, they always tried to live the lives of their people and live together in the midst of their communities by teaching cultural values and Islamic religious teachings. so that it is easily understood and accepted by the Tana Luwu society.41

40 Ritha Ikhsan, "Interview, July 20, 2019”.

41 Syarifuddin David, "Interview, July 20, 2019". 
The connection is with the Sufism Siodja Daeng Mallondjo approach 42 revealed that when Maddika Bua Tandipau had a dialogue with Datok Sulaiman Talking about divinity, then Ampu Lembang To Maroa' and then sang, "Kedo-kedoi na'bombang, Menynyai na'-ware Tenra lessangenna" means: "moving is waves, calm is water that is no different from water". Then, Datok Sulaiman gave an answer by means of Sufism that "those who are worshiped and who worship are united (familiar), because the waves/waves are the same as water, only their nature is different". Then following the singing of the King / Chief of La Tenri Ajeng custom: "Cenna dua ronnang segala dua toi Upawerekkengi ale ri abongngorekku, Abongngoreppa massappa', Pusapoi Mellolongeng ri masagalae" It means: "When are the two substances of God, two also surrender of my stupidity to Him, because only ignorance can seek, and error can get the haq (God). Datok Sulaiman gave an answer with the understanding of Sufism. Knowing because of ignorance and knowing the truth is only self-denial (denying oneself).

Sources that can be used as a reference in using this approach can be seen among others in Surah Al-Mu'minun / 23: 84-90; It means: Say (Muhammad), "Whose the earth, and all that is in it, if you know?". They will say: "Belongs to Allah" Say, "Then will you not remember?". Say, "Who is Lord of the seven heavens and who had the mighty Throne? '. They will say, "(Reserved) God". Say, "then why do you not fear Allah?". Say: "Who His hands are power everything. He protects, and none can be protected (from the punishment of his), if you know? ". They will say, "(belonging to) Allah". Say, "(if so), then how can you be fooled?". Though we have brought the truth to them but they are indeed liars. 43

Third, Supernatural Power Method; when Datok Sulaiman's boat anchored at the Pattimang estuary, it appeared that the boat was seen by bodyguard Datu Luwu (Andi Patiware). Datu

42 Mallondjo, Kedatuan Luwu: Catatan Tentang Sawerigading, Sistem Pemerintahan Dan Masuknya Islam (Palopo: Komunitas Sawerigading, 2008), 79.

43 Departemen Agama RI, Al-Qur'an Dan Terjemahnya (Semarang: Toha Putra, 2008), 79. 
Luwu's guards reported that there were guests, so Datu Luwu immediately made the decision to meet Datok and his friends. Datok Sulaiman holds the title Datok Ri Pattimang with Datok Abdul Makmur Khatib Tunggal with the title Datok Ri Bandang, and Abdul Jawat Khatib Bungsu with the title Datok Ri Tiro. As a tribute to the guests, Datu Luwu asked for their willingness to ascend to the royal palace in Pattimang.

Relation to the supernatural race Abdul Muin Razmal as a community leader revealed that the custom of the kings at that time there was a guest every time the guest was always asked by the king to show his power.44

Furthermore Muis Rahmanu as a religious figure revealed that Datok Sulaiman was a scholar as well as a diplomatic politician so when asked to show his magic he returned to Datu Luwu to show his magic, with full knighthood Datu Luwu immediately took 7 chicken eggs, then he arranged the eggs to top with no fall. After that, then Datu Luwu invited Datok Sulaiman to show his magic. In honor of Datu Luwu, Datok Sulaiman immediately took the egg from each cell with the egg still not falling, as if the egg was hanging.45 Logically, when it is taken between the arranged eggs it must fall. And this apparently did not fall because of the will of Allah Almighty. It was here that Datu Luwu increasingly gained confidence in the nature of the teachings of Islam, and the truth of the existence of God, which was spread by Datok Sulaiman.

The next magic contest, Datu Luwu took a busu (balubu made from the ground), then filled it with water, then stuck it to the wall facing down, busu was attached and any water inside did not fall even not even dripping. In response to Datok Sulaiman for this second round, he immediately broke the busu that was in a state attached to the wall, and then the mute broke, but it turned out that the water in the mute froze and remained attached to the wall without busu again. Jabani as a religious figure revealed that the busu (balubu) was solved, likened to the human body will be destroyed (impermanent) when the time

44 Abdul Muin Razmal, "Interview, August 2, 2019”.

45 Muis Rahmanu, "Interview, August 31, 2019”. 
comes, there is nothing that can prevent / prevent it all happening at the will of the Creator.46

Taufik Abdullah 47 commented that Datu Luwu admit miracle Datok Sulaiman and invited her to his side. Therefore Datok Sulaiman bring the mission of Islam then they invite Andi Patiware converted to Islam, and finally officially Datu Luwu converted to Islam in $1603 \mathrm{M}$.

Datu Luwu with the name Pajung Luwu XV, Andi Patiware Daeng Parabung, also held the title Sultan Muhammad Mudharuddin, his Islamization took place in $1603 \mathrm{M}$ and coincided on 15 Ramadan 1013 H. After Datu Luwu converted to Islam, the authorities and Luwu people followed him. The Islamization of Datu Luwu is spread and maintained with wisdom, not coercion. The implementation of the teachings of Islam in the kingdom of Luwu carried out gradually. Older, noncontradictory values remain in effect mainly in areas outside the Ware' (Pattimang-Malangke).

\section{Conclusion}

The aspects of Islamic teachings developed by Datok Sulaiman are aspects of the creed or monotheism and sharia aspects. Datok Sulaiman developed the aspects of aqidah and sharia because the people of Tana Luwu already had faith in the "Dewata Sewwa-E" before the teachings of Islam were taught.

The methods of spreading Islamic teachings used by Datok Sulaiman in Tana Luwu include; The method of dialogue, the method of Sufism approach, and the method of fighting magic. These three methods are used to convince Datu Luwu the truth of the teachings of Islam as a religion that brings progress, gives salvation to the world and the hereafter.

The entry of Islam in Tana Luwu through the palace door, it was proven that the conversion of Datu Luwu XV Andi Patiware Matinroe Ri Pattimang in 1603 M, which later was titled Sultan Muhammad Waliyul Mudharuddin. Islam spread rapidly throughout the Tana Luwu region as played by Datok

46 Jabani, "Interview, August 1, 2019".

47 Abdullah, Agama Dan Perubahan Sosial (Jakarta: CV. Rajawali, 1983), 340 . 
Sulaiman, now a majority of the population is supported by the support of Datu Luwu.

\section{Bibliography}

Abdullah, Taufik. Agama Dan Perubahan Sosial. Jakarta: CV. Rajawali, 1983.

Ana, Sitti. "Interview." 2019.

Anwar, Idwar. Sejarah Dan Kebudayaan Luwu. Palopo: Pustaka Sawerigading Arung, 2016.

—. Sejarah Luwu: Mengurai Catatan Ringkas Sejarah Luwu Sebelum Kemerdekaan. Palopo: Pustaka Sawerigading, 2010.

Arafah, Muhammad. "Interview.” 2019.

Arikunto, Suharsimi. Prosedur Penelitian Suatu Pendekatan Praktik. Jakarta: Rineka Cipta, 1992.

David, Syarifuddin. “Interview.” 2019.

Hasan, Mohammad Tholchah. Metode Penelitian Kualitatif. Malang: Lembaga Penelitian Universitas Negeri Malang, 2002.

Idris, Muhammad. "Interview.” 2019.

Ikhsan, Ritha. "Interview." 2019.

Jabani. "Interview." 2019. 
Latief, Harisal A. Kedatuan Luwu: Dalam Lintasan Sejarah Dan Kebudayaan. Palopo: Pustaka Sawerigading, 2018.

M.C.Ricklefs. Sejarah Indonesia Modern 1200-2008. Jakarta: PT. Ikrar Andriabadi, 2008.

Mahmud, M. Said. "Interview.” 2019.

Mallondjo, Siodja Daeng. Kedatuan Luwu: Catatan Tentang Sawerigading, Sistem Pemerintahan Dan Masuknya Islam. Palopo: Komunitas Sawerigading, 2008.

Mardalis. Metode Penelitian; Suatu Pendekatan Proposal. Jakarta: Bumi Aksara, 2004.

Mattata, M. Sanusi Dg. Luwu Dalam Revolusi. Ujung Pandang: Bakti Baru, 1967.

Mattulada. Islam Di Sulawesi Selatan. Jakarta: CV. Rajawali, 1983.

Nawawi, Hadari, and Mimi Martini. Penelitian Terapan. Yogyakarta: Gajah Mada University Press, 1996.

Noorduyn, J. De Islamisering van Makasar. Jakarta: Badan Penerbit Kristen, 1956.

Patang, Lahajji. Luwu Dalam Pembangunan. Palopo: Usaha Makmur, 1982.

Pawiloy, Sarita. Ringkasan Sejarah Luwu. Makassar: Telaga Zamzam, 2002.

Rahmanu, Muis. “Interview.” 2019.

Razmal, Abdul Muin. “Interview.” 2019.

RI, Departemen Agama. Al-Qur'an Dan Terjemahnya. Semarang: Toha Putra, 2008. 
Said, Nurhidayat. “Interview.” 2019.

Said, Nurman. "Interview." 2019.

Sewang, Ahmad M. Islamisasi Kerajaan Gowa: Abad XVI Sampai Abad XVII. Yogyakarta: Yayasan Obor Indonesia, 2005.

Sioja, Annas. "Interview.” 2019.

Sioja, Nasrul. "Interview." 2019.

Sugiyono. Metode Penelitian Kuantitatif Kualitatif Dan $R \& D$. Bandung: Alfabeta, 2009.

Suparlan, Parsudi. Agama Dalam Analisis Dan Interpretasi Sosiologis. Jakarta: CV. Rajawali, 1988.

Thohir, Ajid. Perkembangan Peradaban Di Kawasan Dunia Islam. Jakarta: Raja Grafindo Persada, 2009.

Usman, Husaini, and Purnomo Setiady Akbar. Metode Penelitian Sosial. Jakarta: Bumi Aksara, 2001.

Waje, Nidal. "Interview." 2019. 
96 | Bulu'. at.all 